\title{
A Study of Trade Imbalance in Eurozone
}

\author{
Khaled Mohammed Alqahtani ${ }^{1}$ \\ ${ }^{1}$ School of Business, Shaqra University, Saudi Arabia \\ Correspondence: Khaled Mohammed Alqahtani, School of Business, Shaqra University, 11662 Riyadh, P.O. Box \\ 88058, Saudi Arabia. E-mail: dr_alqahtani@su.edu.sa; dr_khaled@126.com
}

Received: May 14, 2019

doi:10.5539/ijbm.v14n8p138
Accepted: June 10, 2019

Online Published: July 10, 2019

URL: https://doi.org/10.5539/ijbm.v14n8p138

\begin{abstract}
Although the trade balance of the Eurozone is close to equilibrium state, the member countries in the zone are facing continuous trade imbalance. This research assumes that the asymmetrical effect of nominal exchange rate of euro and domestic inflation on trade balance is the main reasons for trade imbalance of member states in the Eurozone. Paying great attention to the adjustment effect of domestic inflation on trade balance is an effective way to alleviate trade imbalance in member countries of the Eurozone.
\end{abstract}

Keywords: Eurozone, asymmetry, nominal exchange rate, inflation

\section{Introduction}

Global trade imbalance is one of the hot topics in the field of international finance in recent years. Scholars have focused on the U.S. trade deficit and the long-term trade surpluses of emerging Asian economies, while the trade imbalance among member countries within the Eurozone has not become the focus of this issue. Although the overall trade balance of the Eurozone is close to balance, the trade balance among its member countries is quite different since the establishment of the Eurozone in 1999. Germany, Netherlands, Austria, Finland and other countries have maintained large trade surpluses, while Greece, Portugal, Spain and other countries have experienced serious trade deficits in recent years. And even during the global economic downturn from 2008 to 2010, Germany and Netherlands can still maintain high surpluses. Research reports of the International Monetary Fund (IMF) in 2010 and 2013 pointed out that the trade imbalance between Eurozone member countries has increased since the birth of the euro; and the external imbalance within the Eurozone is severe since the financial crisis. This phenomenon has also aroused debates in academia. For example, Arif Orçun (2013) believed that the trade imbalance among Eurozone member countries was caused by the productivity of deficit countries lagging behind other countries; Florence Jaumotte and Piyaporn Sodsriwiboon (2010) held that the large trade deficit in the countries of the southern Eurozone (SEA) was the result of the decline in private savings rates; Alan Ahearne, et al. (2008) assumed that the external imbalance between Eurozone countries was an embodiment of the euro's own nature and the inappropriate macroeconomic policies. Sun Jie (2011) proposed that the trade structure of the Eurozone itself was asymmetric; the euro exchange rate determined by the overall balance of payments; and economic growth of the Eurozone would continue to maintain the asymmetry between Germany and other Eurozone members. Liao Zefang (2012) supposed that the establishment of the European Monetary Union had promoted the development of the economies inside and outside the zone, and had led to the expansion of domestic credits and the increase of foreign capital inflows in the peripheral countries, thus providing a source of financing for their trade deficits.

Most of the above literature started from a single perspective, such as exchange rate, income, trade structure and so on. In fact, the trade imbalance between Eurozone member countries is caused by the joint effects of many factors. In this research, the trade imbalance in Eurozone is studied from the view of "two asymmetrical effects". The first asymmetrical effect refers to the different effects of the nominal exchange rate of the euro on the trade balance of surplus and deficit countries. The second one refers to the different impacts of domestic inflation on surplus countries and deficit countries. Those two asymmetrical effects are important factors of trade imbalance in the members of Eurozone.

\section{Theoretical Analysis of Two Asymmetrical Effects in Eurozone}

Trade balance and imbalance is an important topic in international economics research. From the perspective of elasticity approach, the mechanism of two asymmetrical effects on trade imbalance in the Eurozone is explained 
in this research. About the asymmetry, Mundell assumed that the demand for products from country (or region) A suddenly dropped compared with country (or region) B, if the two countries (or regions) were based on a fixed exchange rate system, tightening monetary credit by the monetary authority of country A would lead to an increase in interest rates and an improvement in the balance of payments, which would inevitably reduce the demand for products from country B, thus leading to multiple deflation. Copeland stressed: the above problems were caused by the basic asymmetry of the fixed exchange rate system, that is, although the adjustment of monetary policy in country A had improved its domestic balance of payments, it had worsened the balance of payments in country B. Hence, under the common currency system, is there still an asymmetrical effect? In this research, the asymmetrical effect under the fixed exchange rate system is extended to the asymmetrical effect in the common currency area such as the Eurozone.

The real exchange rate refers to the relative price index of domestic and foreign commodities after inflation factor is eliminated. The devaluation of the real exchange rate and the competitive advantages of domestic commodities in the international market may promote the export of domestic commodities, resulting in a trade surplus, and vice versa. This research assumes that the foreign price level will remain unchanged during the investigation period, and focuses on the discussion of asymmetrical effect caused by the changes in nominal exchange rate and domestic price level.

\subsection{The Explanation of Nominal Exchange Rate}

The trend of the euro reflects not only the situation of strong economy entities (such as Germany and Netherlands) but also that of weak ones (such as Greece, Spain and Portugal). Moreover, the common currency weakens the adjustment of nominal exchange rate on the trade imbalance of individual countries. These have a certain blocking effect on their trade balance. Just imagine, if Germany continues to use the Mark as its own currency, according to the theory that countries with current account surpluses are under pressure to appreciate their currency, the Mark would be substantial appreciation, thus narrowing its huge trade surplus. However, the current account of the Eurozone as a whole is close to balance, and the overall situation of the euro exchange rate is relatively stable (see Figure 1). This relatively stable exchange rate has become a favorable condition for Germany to maintain a trade surplus. If Greece continues to use the Drachma as its own currency, the devaluation of the Drachma may improve its trade deficit to some extent. However, the relatively stable exchange rate of the euro does not provide such possibilities for Greece and other countries. On the contrary, the appreciation of the euro within a certain range has worsened the trade deficits of Greece, Spain, Portugal and other countries. Therefore, under the single euro currency system, the nominal exchange rate has different effects on the trade balance adjustment of various countries. Such asymmetry is an important reason for the trade imbalance among the countries within the Eurozone.

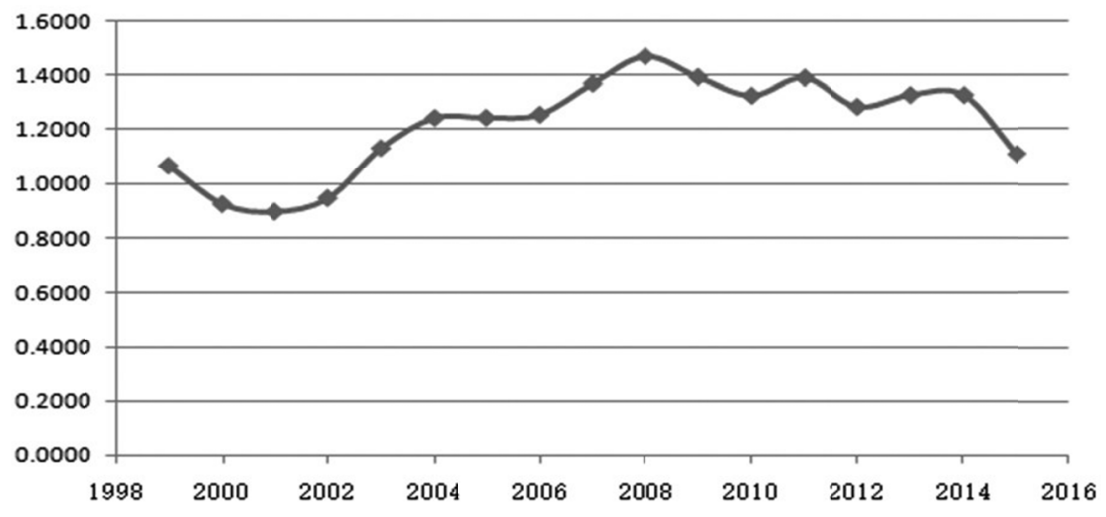

Figure 1. Nominal Exchange Rate of Euro to US Dollar

\subsection{The Explanation of Domestic Price Level}

Figure 2 below describes the annual data of GDP deflator of major countries in Eurozone. We can see that German GDP deflator is always below the Eurozone's GDP deflator, that of the Netherlands is slightly higher, and that of Greece, Portugal and Spain are far higher. Based on this fact, the second asymmetric effect originates from the inflation differences in the member states of the Eurozone. Under the condition of common monetary policy and the same nominal exchange rate, the difference of real exchange rate mainly depends on the inflation 
difference of different countries. The lower inflation rates in Germany and the Netherlands made their real exchange rates lower, thus promoting their trade surpluses. Higher inflation rates in Greece, Spain, Portugal and other countries caused the appreciation of real exchange rate, thus aggravating the trade deficit. Due to the free customs duties and the trade integration within the Eurozone, the relatively low inflation rates in Germany and the Netherlands are also conducive to the accumulation of intra-zone trade surplus. Whether Eurozone member countries trade outside or inside the Eurozone, domestic inflation has an important impact on their trade balance.

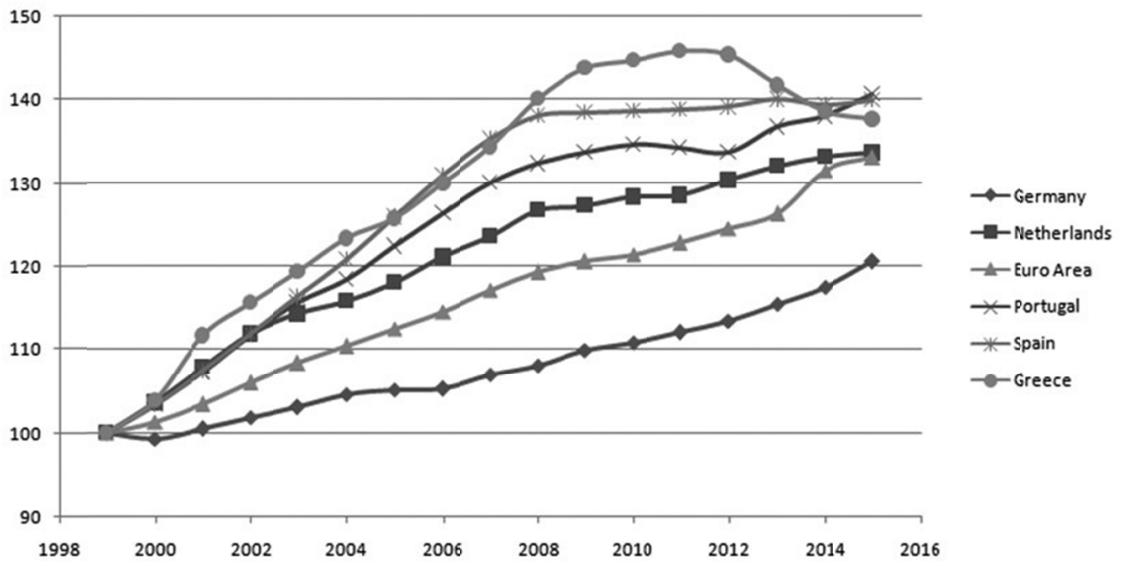

Figure 2. GDP Deflator of Major Countries in Eurozone

\section{Model Setting, Variable Selection and Data Collection}

\subsection{Model Setting}

Based on the above analysis, combined with the existing literature research results, a comprehensive model on trade balance is established. With nominal exchange rate and domestic GDP deflator as explanatory variables respectively, econometric test models are established in this research as follows:

$$
\begin{aligned}
& T B t=C+\beta 1 N E E R t+\beta 2 G D P \text { deflatort home }+\beta 3 G R O W T H t+\beta 4 F B t+\beta 5 \text { PRODUCTIVITYt }+\beta 5 G D P \text { deflatort } \\
& \text { foreign }+u t
\end{aligned}
$$

The explained variable of the model is $T B t$, which indicates the percentage of one country's trade balance in GDP. One of the explanatory variables is the nominal effective exchange rate index of the euro, expressed as NEERt. The second explanatory variable is domestic GDP deflator, which measures the domestic inflation situation and is expressed as GDP deflatort home.

Control variables include one country's economic growth rate expressed as $G R O W T H_{t}$; the financial balance rate expressed as $F B_{t}$, which is equal to the proportion of one country's financial balance in GDP; labor productivity per capita in one country expressed as PRODUCTIVITY $Y_{t}$; the inflation index of one country's trading partners expressed as GDP deflatort ${ }^{\text {foreign }}$; disturbing term expressed as $u_{t}$. It should be noted that due to the availability of data, the labor productivity per capita $P R O D U C T I V I T Y_{t}$ is the unit labor productivity of one country.

\subsection{Variable Selection and Data Collection}

In this research, Germany and Netherlands are chosen as a group of surplus countries, while Greece, Portugal and Spain are chosen as a group of deficit countries. In addition, econometric tests are conducted on five countries one by one. Therefore, the different effects of independent variables on the trade balance of each country can be clearly measured. This is convenient for the comparison among countries as well. The time interval corresponding to each index is from the first quarter of 2002 to the fourth quarter of 2014. The statistics are derived from the IFS Database of International Monetary Fund (IMF) and the Database of EU-ROSTAT. The data of foreign GDP deflator are selected from the average value of GDP deflator of 9 countries including G7 countries, China and India. 


\section{Empirical Analysis}

\subsection{Enger (EG) Two-Step Method}

The original data of each variable is unstable, but the data after the first-order difference is stable, so all these variables can be determined to be first-order single-integer stationary sequences. Next, the co-integration test method proposed by Engle and Granger (1987), namely EG Two-step Method, is used to test whether there is co-integration relationship between dependent variables and independent variables.

Step one, OLS estimation is performed on the regression equation to obtain the regression results shown in Table 1.

Step two, the unit root test is conducted on the residual error ût (see Table 1.2), that is, the residual error of the regression equation is a stationary sequence is checked.

$$
\begin{gathered}
\hat{u} t=T B t-C-\beta 1 N E E R t-\beta 2 G D P \operatorname{def} \text { latort }{ }^{\text {hom e }}-\beta 3 G R O-W T H t-\beta 4 F B t-\beta 5 P R O D U C T I V I T Y t- \\
\beta 5 \text { GDPdeflatort foreign }
\end{gathered}
$$

Table 1. Results of OLS estimate regression

\begin{tabular}{llllll}
\hline Variable & Germany & Netherlands & Greece & Portugal & Spain \\
\hline \multirow{2}{*}{ C } & 0.046984 & $-23.1802^{* *}$ & $-44.30136^{* *}$ & $-35.89641^{* *}$ & 10.62360 \\
NEER & $(13.30851)$ & $(9.322051)$ & $(25.80159)$ & $(15.24594)$ & $(14.66428)$ \\
GDP deflator ${ }^{\text {home }}$ & $0.101165^{* *}$ & $0.190095^{* *}$ & $-0.690790^{* *}$ & $-0.027376^{* *}$ & -0.115301 \\
& $(0.050515)$ & $(0.084857)$ & $(0.381331)$ & $(0.164588)$ & $(0.139857)$ \\
GROWTH & 0.095832 & -0.116245 & $-1.390329 * * *$ & $-1.062722^{* * *}$ & $-0.656722^{* * *}$ \\
& $(0.158464)$ & $(0.230496)$ & $(0.345439)$ & $(0.214167)$ & $(0.098346)$ \\
FB & $0.176677^{* *}$ & $0.223942^{* *}$ & $-0.961647 * * *$ & $-0.233099 *$ & $-0.601821^{* * *}$ \\
& $(0.067617)$ & $(0.100121)$ & $(0.271479)$ & $(0.140928)$ & $(0.120788)$ \\
PRODUCTIVITY & $0.212567 * * *$ & 0.015284 & -0.134123 & 0.100247 & 0.039622. \\
& $(0.065705)$ & $(0.037222)$ & $(0.134557)$ & $(0.077560)$ & $(0.068707)$ \\
GDP deflator foreign & -0.126087 & 0.004170 & $1.024956^{* * *}$ & $0.488269 * *$ & -0.037828 \\
Number of observations & $(0.0888187)$ & $(0.077240)$ & $(0.179407)$ & $(0.185274)$ & $(0.107806)$ \\
DW & -0.014357 & $0.256563 *$ & $1.343122^{* * *}$ & $0.921577 * * *$ & $0.690152^{* * *}$ \\
R2 & $(0.098217)$ & $(0.138229)$ & $(0.214579)$ & $(0.147213)$ & $(0.100271)$ \\
\hline
\end{tabular}

Note. The data in the brackets are standard deviation; *** refers to $\mathrm{p}<0.01,{ }^{* *}$ refers to $\mathrm{p}<0.05$ and $*$ refers to $\mathrm{p}<0.1$.

Table 2. Results of Unit Root Test of Residual Error

\begin{tabular}{llllll}
\hline & Germany & Netherlands & Greece & Portugal & Spain \\
\hline \multirow{2}{*}{ Intercept } & $-5.498021^{* * *}$ & $-3.248987^{* *}$ & $-2.614518^{*}$ & $-5.269213^{* * *}$ & $-4.714791^{* * *}$ \\
& $(0.0000)$ & $(0.0233)$ & $(0.0979)$ & $(0.0001)$ & $(0.0004)$ \\
\multirow{2}{*}{ Trend } & and & & & & \\
Intercept & $-5.431050^{* * *}$ & $-3.303707^{*}$ & $-2.615727^{*}$ & $-5.207227^{* * *}$ & $-4.614951^{* * *}$ \\
& $(0.0002)$ & $(0.0781)$ & $(0.2757)$ & $(0.0005)$ & $(0.0030)$ \\
\multirow{2}{*}{ None } & $-5.554744^{* * *}$ & $-3.239455^{* * *}$ & $-2.645753^{* * *}$ & $-5.321059^{* * *}$ & $-4.759134^{* * *}$ \\
& $(0.0000)$ & $(0.0017)$ & $(0.0093)$ & $(0.0000)$ & $(0.0000)$ \\
\hline
\end{tabular}

Note. The data in the brackets are $\mathrm{p}$ values; ${ }^{* * *}$ refers to $\mathrm{p}<0.01$, ** refers to $\mathrm{p}<0.05$ and $*$ refers to $\mathrm{p}<0.1$; null hypothesis is $\mathrm{H} 0=\mathrm{unit}$ root (Sequence is unstable) and alternative hypothesis is $\mathrm{H} 1>0$ (Sequence is stable).

The results in Table 2 shows that the û sequence of Germany, Spain and Portugal rejected the null hypothesis at a significance level of $1 \%$, whereas the û sequence of Netherlands and Greece rejected the null hypothesis at a significance level of $10 \%$. This shows that the residual error of each sample is a stationary sequence, i.e. $\hat{u} \sim \mathrm{I}(0)$. Therefore, the hypothesis that dependent and independent variables are co-integrated is accepted, there is a stable equilibrium relationship between dependent and independent variables, and the model setting is correct. 


\subsection{Analysis of Measurement Results}

The regression results in Table 1.1 show that: Regarding one of the explanatory variables (the nominal effective exchange rate index of the euro), first of all, the nominal exchange rates of Germany and the Netherlands have a stable and significant positive effect on domestic trade balance (significant at a level above 90\%). In theory, the appreciation of one country's nominal exchange rate should be detrimental to its export trade. This result seems to be contrary to economic theory. In fact, it suggests that after the formation of the Eurozone, the appreciation of nominal exchange rate of the euro has not brought adverse effects on Germany and the Netherlands, but has promoted their trade surplus to a large extent. One reasonable explanation is that the current account of the Eurozone was close to balance during the investigation period. According to the WEO database of International Monetary Fund (IMF), the CA/GDP in the Eurozone remained below 2\% in all other years except $-2.6 \%$ in 2000 and $2.3 \%$ in 2004. However, Germany and the Netherlands have been the countries with large current account surpluses. In most years, their CA/GDP has remained above 5\%, with Germany's highest value reaching $7.4 \%$ (2014) and the Netherlands's highest value reaching $11.0 \%$ (2013). According to the above theoretical analysis, the euro has no appreciation pressure in general. And there is a stable exchange rate environment in the Eurozone currently. For Germany and Netherlands, if their own currencies are still adopted, the huge current account surplus will greatly promote the appreciation of their domestic currencies. Therefore, a single euro currency system weakens the link between the current account and the exchange rate, and reduces the automatic adjustment between them. The nominal exchange rate of the euro continues to be undervalued against Germany, the Netherlands and other countries. In this case, even if the euro appreciates slightly, because the critical point to reverse its undervalued exchange rate has not been reached, the appreciation of exchange rate will still not have a negative effect on the trade balance of Germany and the Netherlands. The balance of payments continuously closing to the balance in the Eurozone and the relatively stable exchange rate environment of the euro are important factors for Germany, the Netherlands and other countries to maintain large surpluses. Secondly, the appreciation of the nominal exchange rate of the euro has a significant negative effect on the trade deficits of Greece and Portugal (significant at a level above 95\%). This shows that the exchange rate factor is an important reason for these countries' deficits. In particular, during the continuous appreciation of the euro from 2004 to 2008, Greece's trade deficit also expanded rapidly. This also objectively confirms the importance of the exchange rate to the trade imbalance of deficit countries. In addition, the nominal exchange rate of euro is negatively correlated with Spain's trade balance, but it is not significant. This may be due to the fact that after 2012, Spain's trade deficit had continuously improved to close to balance and gradually turned into surplus, weakening the adverse impact of the overvaluation of exchange rate on trade balance. In fact, if the investigation interval ends in 2012, it can be found that that Spain's nominal exchange rate has a significant negative effect on its trade balance (significant at a level above 95\%), with a coefficient of -0.355252 . Generally speaking, the appreciation of the nominal exchange rate of the euro has opposite effects on the trade balance between surplus countries and deficit countries and has obvious asymmetrical effect.

In terms of the second explanatory variable (domestic GDP deflator), firstly, the rising inflation in Germany and Netherlands has a positive effect on their trade balance, but the effect is not significant. According to economic theory, the rise of domestic inflation has a reverse effect on trade balance. However, Germany and the Netherlands not only avoid this adverse effect, but also show a positive correlation on trade balance. This may be due to the fact that the moderate inflation of Germany and Netherlands pushed their real exchange rates lower than that of other countries, pushing up their domestic trade surpluses during the investigation period. On the other hand, under the background of free customs duties, free labor flow and economic integration in the Eurozone, the low inflation rate in Germany and Netherlands makes their trade in the Eurozone develop rapidly. For example, France ranked first as the Germany's major trading partners, and five of the top ten are all Eurozone countries in 2014. The moderate inflation of Germany and Netherlands had even more highlighted their price advantages in the Eurozone trade activities. Secondly, the inflation in Greece, Spain, Portugal and other countries has a fairly negative effect on their trade balance (significant at a level above $95 \%$ ). This is not only because the high inflation rate had increased their real exchange rates and aggravated their trade deficits, but also because the high inflation rate of deficit countries enabled them at a low price disadvantage in intra-regional trade activities. Therefore, the appreciation of the rise of domestic inflation has opposite effects on the trade balance between surplus countries and deficit countries and has also obvious asymmetrical effect.

In addition to the two explanatory variables, the impact of some control variables on trade balance is also reflected in Table 1. From the significance and coefficient of each control variable, it is found that the economic growth rate has a significant positive effect on the trade balance of surplus countries and a significant negative effect on the trade balance of three deficit countries. This may be due to the fact that the faster the economic 
growth rate is, the higher the savings rate will be (Fry and Mason, 1982). Higher economic growth rates in Germany and the Netherlands increased their domestic savings rates and promoted trade surpluses. But in Greece, Spain, Portugal and other countries, the increase in economic growth rate increased the consumption expenditure of their residents and exacerbated the trade deficit. The fiscal balance rate has a positive and significant effect on Germany's trade balance and is not significant for other countries. This shows that Germany's prudent fiscal policy for a long time is an important reason for maintaining its trade surplus. Besides, labor productivity has a positive and significant effect on Greece's trade balance; it is positively related to the Dutch trade balance, and it is negatively related to the trade balance of deficit countries but not significant. This may be because during the investigation period, the growth of Greece's labor productivity came from the trade sector, and the increase in productivity expanded the output of the trade department, thus having a favorable impact on the trade balance. However, productivity growth in other countries was inclined to non-trade sectors such as service industry and financial industry. Hence, the productivity has a reverse or no significant relationship with domestic trade balance. However, the foreign GDP deflator has a significantly positive relation to the trade balance of all deficit countries. This shows that the rise in foreign price level eased the trade deficit of deficit countries to some extent, but this positive effect cannot offset the sum of other negative effects.

\section{Conclusion}

The above analysis shows that nominal exchange rate and domestic inflation have obvious asymmetrical effects on the trade balance of surplus and deficit countries in the Eurozone. Surplus countries can evade the adverse effects of the appreciation of euro nominal exchange rate and the rise of domestic inflation on trade balance. On the other hand, trade deficits of deficit countries can be explained to a large extent by the appreciation of euro nominal exchange rate and their high inflation rate. This asymmetry shows that adjusting the trade imbalance in the members of Eurozone by adopting exchange rate policies is ineffective, and even leads to a greater gap. Under the condition that the nominal exchange rate of the euro cannot be changed, paying full attention to the transmission effect of domestic inflation on trade balance may be an effective way for Eurozone member countries to alleviate their trade imbalance. Surplus countries can appropriately raise their wages, increase labor costs and adjust price levels to reduce trade surpluses.

Moreover, deficit countries can increase the competitiveness of their export industries and reduce trade deficits by cutting wages and prices. However, it has certain challenges to improve the trade imbalance simply by adjusting prices, which is difficult to gain the approval of surplus countries and convince the public of deficit countries. Therefore, while paying attention to the effect of domestic inflation on trade balance, member governments can also redistribute resources in their trade and non-trade sectors. Surplus countries can raise the relative prices of non-trade sectors relative to trade sectors and guide domestic resources to non-trade sectors such as medical care, services and public utilities. This will not only reduce the proportion of the trade sector and the trade surplus, but also help to improve the living standards of the local residents. The deficit countries need to raise the price level of trade sectors relative to non-trade sectors, guide the transfer of domestic resources to trade sectors, and promote the continuous development of foreign trade. For the single currency union of the Eurozone, to improve the trade imbalance among member countries, not only shall attention be paid to the roles of nominal exchange rate and price factors, but also the influence of fiscal policy, economic growth rate, productivity and other factors shall be cared about. In addition, the mutual coordination ability among countries shall be enhanced, the real differences shall be recognized, and all member countries shall jointly face the new problems and tests that may occur.

\section{References}

Blanchard, O., \& Giavazzi, F. (2002). Current account deficits in the Euro area: the end of the feldstein horioka puzzle, Brookings Papers on Economic Activity, 33(2).

Ca' Zorzi, M., Chudik, A., \& Dieppe, A. (2009). Current account benchmarks for Central and Eastern Europe: a desperate search? ECB Working Paper, 995.

Calderon, C. A., Chong, A. \& Loayza, N.V. (2002). Determinants of current account deficits in developing countries, Contributions to Macroeconomics, 2(1), Article 2.

Cheung, C., Furceri, D., \& Rusticelli, E. (2010). Structural and cyclical factors behind current-account balances, OECD Economics Department Working Papers, No. 775. https://doi.org/10.1111/roie.12080

Chinn, M., \& Prasad, E. (2003). Medium term determinants of current accounts in industrial and developing countries: An empirical exploration, Journal of International Economics, 59(1). http://dx.doi.org/10.2139/ssrn.337227 
Dooley, M., Folkerts-Landau, D., \& Garber, P. (2009). Bretton woods II still defines the international monetary system. Pacific Economic Review, 14, 297-311.

Jaumotte, F., \& Sodsriwiboon, P. (2010). Current account imbalances in the Southern Euro Area: causes, consequences and remedies, IMF Working Paper, No. 10/139. Retreived from http://www.dt.tesoro.it/export/sites/sitodt/modules/documenti_it/analisi_progammazione/eventi/Jaumotte Sodsriwiboon.pdf

Kollman, R. (1998). US trade balance dynamics: the role of fiscal policy and productivity shocks and of financial market linkages, Journal of International Money and Finance, 17, 637-669.

\section{Copyrights}

Copyright for this article is retained by the author(s), with first publication rights granted to the journal.

This is an open-access article distributed under the terms and conditions of the Creative Commons Attribution license (http://creativecommons.org/licenses/by/4.0/). 